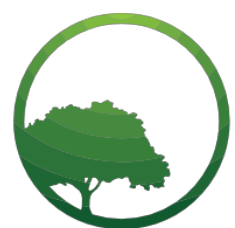

Business \& Social Science IJRBS

\section{Research in Business and Social Science}

IJRBS Vol 8 No 1, ISSN: 2147-4478

Contents available at www.ssbfnet.com/ojs

\title{
The Role of Satisfaction in Mediating the Effect of Services Quality on The Customers' Loyalty in The Village Credit Institution of Pekraman, Tabanan
}

\author{
Anak Agung Ngurah Gede Sadiartha
}

Lecturer of Economic Faculty, University of Hindu Indonesia (UNHI) Denpasar

\section{Gusti Ayu Mirah Apsari}

The Economic Faculty, University of Hindu Indonesia (UNHI) Denpasar

\begin{abstract}
Loyalty is a deep commitment to repurchase a product or service that becomes a preference consistently in the future by repurchasing the same product. The problem formulation in this study is how are the direct and indirect effects of services quality through satisfaction on the consumers' loyalty. This study aims to know the direct and indirect effect of services quality through satisfaction on the consumers' loyalty. The study was conducted by the village credit institution of Pekraman, Tabanan located in Gajah Mada street 107, Tabanan. The number of samples is 94 customers with slovin's formula and accidental sampling method. The techniques of data collection used were interviews, documentation, literature review and questionnaire. The research instruments used were validity test and reliability test. The technique of data analysis used was path analysis with sobel test. Based on the result of calculation, it showed that the services quality had a positive and significant effect on the customers' satisfaction in the village credit institution of Pekraman, Tabanan as many as 0,000<0,05. Thus, $\mathrm{HO}$ was rejected and $\mathrm{H} 1$ was accepted. The customers' satisfaction had a positive and significant effect on the customers' loyalty in the village credit institution of Pekraman, Tabanan as many as 0,000 $<0,05$. The services quality had a positive and significant effect of the customers' loyalty in the village credit institution of Pekraman, Tabanan as many as $0,000<0,05$. Thus, $\mathrm{HO}$ was rejected and $\mathrm{H} 3$ was accepted. Based on the result of calculation, it showed that Zcount $(5,323)>Z$ table $(1,96)$. Thus, the customers' loyalty can mediate the relationship between customers' services quality and loyalty on the village credit institution of Pekraman, Tabanan. For the services quality, it is needed to improve the services given to the customers. For instance, it is provided the more exciting interest adjusted to the type of savings chosen by the customers so they will feel more satisfied and can develop their loyalty.
\end{abstract}

Key words: Services Quality, Customers' Satisfaction, Customers' Loyalty

JEL classification: $015, P 36$

Submitted: 14.10.2018 - Accepted: 19.02.2019

\section{Introduction}

In this modern era, there are so many companies competing to be the best one. The progress 
of technology and rapid rivalry in the globalization era makes companies always adapt to the changes happened in the business environment. Whether being successful in getting the objective or not depends on the services and information about consumers' characteristic. The relationship between consumers and company is need keeping continuously. In the situation with rapid rivalry, generally consumers do not have high level loyalty, because there are so many offers given to them and surely they will choose the most beneficial offer (Bloemer et al., 2000).

The loyal consumers tend not to do switching and become strong word of mouth (Darsono, 2004). According to Kotler dan Keller (2011: 138), loyalty is a commitment held strongly to buy or support the products or services that will be liked in the future. To improve the consumers' loyalty on the company is not easy. Generally, consumers' loyalty is an attitude showing the connection of consumers in choosing or using products. The consumers' loyalty has an important role in a company. Maintaining them means improving the financial performance and maintaining keeping the existence of company. This becomes the main reason for companies to attract and maintain their consumers. According to Hasan (2008:83), the consumers' loyalty refers to consumers who not only buy products and services, but also recommend to others. Services quality is an important factor in maintaining consumers. Each company always tries and competes to give the best services in order to make the consumers move to other company. According to Kotler dalam Tjiptono (2000:6), service is basically an activity or benefit offered by a group to another group that is intangible and does not produce things. The services quality gives a support to the customers to have a strong bond to the company.

The bond occurring in a long time is able to make the company understand the customers' expectation and need. Thus, the company can improve the customers' satisfaction, where it maximize the customers' good experiences and minimize the customers' bad experiences. Company that is incapable of satisfying its customers will have difficult problem. Thus, the rivalry is greatly affected by the capability of bank providing the best services than others. Services quality is related to customers' satisfaction. The quality really motives the customers to have a beneficial bond with the company in a long period. It is surely able to make the company understand the customers' expectation and specific need, so it can reach the customers' loyalty (Tjiptono 2011). The customers' loyalty is one of success secret of the company, but there are many people forgetting it. There are many business failures occurring, because the customers is disappointed. Then they look for other alternative products or services. In the theory of consumer behavior, satisfaction is mostly defined from the perspective of consumers' experience after consuming or using products or services. Thus, satisfaction can be defined as the consumers' perception about the products or services that make them satisfied. The level of satisfaction refers to what the consumers feel and expect (Palilati, 2004). As the customary law community, the traditional village in Bali functions to preserve, maintain, and utilize the resources of the traditional village for community prosperity. It indicates the traditional village has an autonomy in the social economics field. Considering the role and contribution of traditional village, the government of Bali province issues a local regulation no. 8 of 2002 about the village credit institution. It is a saving and loan entity owned by traditional village. $T$

The village credit institution is an extraordinary financial institution. It is a special institution owned by Balinese community. The aspect of capital in the village credit institution is so different from other financial institution such as bank or saving and loan cooperative. From the aspect of capital, it can be indicated that the village credit institution is a special financial institution owned by the community, because the capital comes from the Pekraman village that 
is Balinese community. Either bank or saving and loan cooperative gets capital from its members or shareholder. The capital of village credit institution is owned by the community. Thus, the responsibility is for community through sangkepan (meeting) in Pekraman. The village credit institution of Pekraman, Tabanan is an institution obtaining fund from society and share to them in the form of saving, deposit, or credit and try to give the best services for all the customers. Since the village credit institution of Pekraman, Tabanan was established, it has done efforts to build a good corporate image by donating to the customers' family that is passed away, giving presents to the customers, giving low interest to the customers, and participating in building Kahyangan Tiga temple by giving donation.

The big number of credit donated by the village credit institution of Pekraman, Tabanan will implicate to the services for customers, especially for credit. Besides the bigger number of credit, it also needs more services and accuracy. The hard effort in developing the company has been conducted by the village credit institution of Pekraman, Tabanan, but the customers' satisfaction becomes the expectation of village credit institution of Pekraman, Tabanan. The number of credit and customers in the village credit institution of Pekraman, Tabanan from 2011 to 2017 can be viewed on the table 1.1 below.

Table 1: The Number of Credit and Customer in The Village Credit Institution of Pekraman, Tabanan from 2011 to 2017

\begin{tabular}{|l|l|l|l|l|}
\hline Year & $\begin{array}{l}\text { Number of Credit } \\
\text { Rp. }\end{array}$ & $\begin{array}{l}\text { Percentage } \\
\text { \% }\end{array}$ & Number of Customer & $\begin{array}{l}\text { Percentage } \\
\%\end{array}$ \\
\hline 2013 & 27.834 .464 .425 & - & 1.285 & - \\
\hline 2014 & 30.151 .247 .125 & $8 \%$ & 1.304 & $1,48 \%$ \\
\hline 2015 & 38.872 .280 .625 & $29 \%$ & 1.296 & $-0,61 \%$ \\
\hline 2016 & 58.224 .694 .275 & $50 \%$ & 1.408 & $8,64 \%$ \\
\hline 2017 & 70.492 .196 .750 & $21 \%$ & 1.436 & $1,99 \%$ \\
\hline
\end{tabular}

Source : The village credit institution of Pekraman, Tabanan (2018)

From the table 1.1 , it indicate that the number of credit given by The village credit institution of Pekraman, Tabanan was increasing from 2013 to 2017. It is different from the number of customer that was either increasing or decreasing. The big number of credit donated by the village credit institution of Pekraman, Tabanan will implicate to the services for customers, especially for credit. Besides the bigger number of credit, it also needs more services and accuracy. The customers' satisfaction created by the services quality will give several benefits, such as a good relationship between the company and the customers, that intends to customer retention. It also motivates the customers' loyalty that intends to many purchases, make recommendation by word of mouth. Then the proportion of purchase can increase the benefit of company. Based on the explanation above, what motives the researcher to take a research is the importance of services quality in order to improve the customers' satisfaction that will affect on the customers' loyalty and improve the existence of the village credit institution of Pekraman, Tabanan. Thus, it is entitled "TheRole of Satisfaction in Mediating the Effect of Services Quality on the Customers' Loyalty in The village credit institution of Pekraman, Tabanan".

\section{Literature Review}

\section{Loyalty}

The customers' behavior is a part of human activities that always change in accordance with the effect of social environment where they are in. The customers' behavior expected by the company is loyalty. Loyalty means that the customers purchase regularly. In general, loyalty can be defined as one's faithfulness toward products or services. There are some definitions of loyalty according to experts.

According to Kotler (2009:138), loyalty is a commitment held deeply to repurchase or support the products or services liked in the future although the effect of situation and effort makes the customers 
move to others. According to Tjiptono (2011:481), purchasing for many times is related to purchase a brand for many times. The concept about loyalty is an old concept in marketing and always grows with various variants According to Grifin (2002:4), (in Hurriyati, 2010, page 128) states loyalty is defined as non random purchase expressed over time by some decision-making units. Based on the definition, it indicates that loyalty tends to a behavior, namely purchasing for many times based on decision-making unit. Customers' loyalty is generally an attitude showing the connection of customers in choosing and using a product. Customers' loyalty has an important role in a company. Maintaing them means improving the financial performance and the exixtence of company. It becomes the main reason for a company to attract and maintain the customes. Customers' loyalty refer to customers not only purchasing products or services but also recommending to others, according to Hasan (2008:83). Customers' loyalty is defined as a loyalty showed by the customers on the products provided by the company. The indicator of research used was based on the theory stated by Griffin (2005). Some indicators used to measure the customers' loyalty is repeat purchase (customers' loyalty on products or services). Reward is a loyalty where the customers use various products provided by a company. Recommendation is sharing information about products or services to others. Refuse is being not attracted to other company. Based on the explanation above, it can be concluded that customers' loyalty is customers who purchase products or services repeatedly. Then the customers will convey and recommend others to try the products or services. Finally, they will be loyal to the products or services and reject products or services from other company.

\section{Services Quality}

Services cannot be seen, felt, smelled, and heard as concrete products, so the assessment of services quality is different from goods. Services have certain characteristics. How the customers assess the services determines the services quality. Discussing about the quality of banking company is surely not separated from services quality. Service quality is an effort to fulfill the customers' needs and wishes and the accuracy of information distribution in balancing the customers' wish, according to Tjiptono (2007). According to Ariani (2009:205), services quality is a global attribute of company and customers' consideration on the superiority of company completely. The services quality can be indicated by comparing between the customers' perception on the real services they got and services they expect. If the services are sutitable with what they expect, a good perception will be created. If the services are more than what they expect, a very good perception will be created. If the services are not suitable with what they expect, a bad perception will be created. The indicators of services quality according to zheithalm et al dalam Ariani (2009:180) that is known as SERQUAL (Service quality) consisting of Tangible, Reliability, Reponsiveness, assurance are knowledge, hospitality, employees' ability to build self-confidence for company and empathy.

\section{Customers' Satisfaction}

According to Kotler cited by Fandy Tjiptono (2011: 312), customer's satisfaction is one's feeling after comparing between performance he perceives and his expectation.. According to Kotler dan Keller (2009: 138), satisfaction is one's happiness or sadness created after comparing between the products have been perceived and the expectation. If the performance fails to fulfill the expectation, the customers will not be satisfied. If the performance is in accordance with the expectation, the customers will be satisfied. If the performance is more than the expectation, the customers will be very satisfied or happy. The assessment and emotional response is shown by the customers after purchasing process by comparing between the actual performance on the product and the expectation, anf evaluation in cosuming the products or services. According to Tjiptono (2004:101), the indicator of customers' satisfaction includes suitability with expectation, interest to come back, readiness to recommendd 


\section{Research and Methodology}

\section{Research Design}

Loyalty is a deep commitment to repurchase a product or service liked in the future. TO improve the consumers' loyalty on the company is not easy. The consumers' loyalty is generally an attitude showing the connection of consumers in choosing and using products. The consumers' loyalty has an important role in a company. Maintaining them means improving the financial performance and the existence of company. It is the main reason of company to attract and maintain its consumers. It is needed to maintain the customers' loyalty such as providing good services and making customers satisfied for all activities conducted by the company. The consumers' satisfaction created through the services quality will give some benefits, such as good relationship between customers and company that refers to customer retention and support the customers' loyalty that refers to purchasing repeatedly, recommendation word by mouth, and proportion of purchase that can increase the benefit of company. This study aims to analyze the role of satisfaction in mediating the effect of services quality on the sustomers' loyalty in the village credit institution of Pekraman, Tabanan.

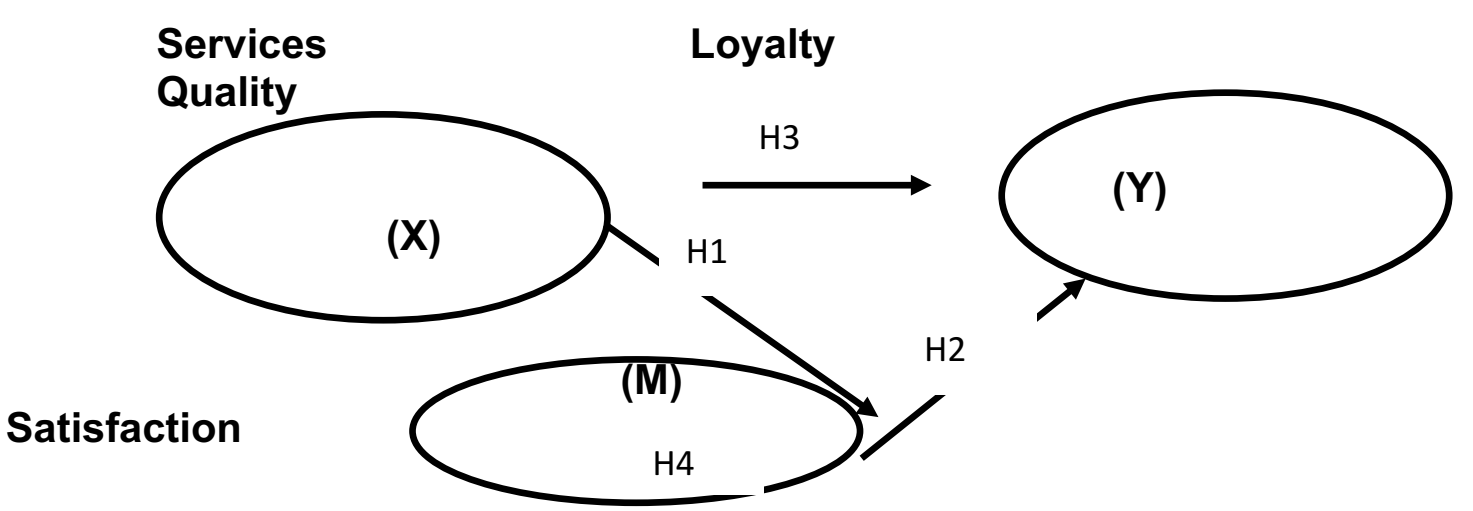

Source : Mind Mapping of Researcher (2018)

Figure 1: Research Design of The Role of Satisfaction in Mediating the Effect of Services Quality on the Customers' Loyalty in the Village Credit Institution of Pekraman, Tabanan

Based on the main problem that has been formulated in the hypothesis, the variables analyzed in this study were services quality $(X)$ as a independent variable, satisfaction $(M)$ as a mediating variable and customers' loyalty $(\mathrm{Y})$ as a dependent variable. It used a qualitative approach that was descriptive. In this study, it was conducted an observation on some variables to describe something from variables examined (Istianto, 2006:22). It was specially conducted an observation on the services quality, satisfaction, and customers' loyalty. The data used in this study were numbers analyzed using statistics. It was analyzed using path analysis with Sobel test(Preacher dan Hayes, 2004).

\section{Location of Research}

This study was conducted in the village credit institution of Pekraman, Tabanan located in Gajah Gada street 107, Tabanan. The author will take a research by visiting the village credit institution of Pekraman, Tabanan to gather supporting data for this study. 


\section{Object of Research}

The objects of this study were effect of services quality, corporate image, and customers' satisfaction the village credit institution of Pekraman, Tabanan located in Gajah Gada street 107, Tabanan

\section{Population and Sample}

Population

The population that became the object of this study was all customers in the village credit institution of Pekraman, Tabanan in 2017 as many as 1.436 people (table 1.1)

\section{Sample}

The sample in this study was taken by using Slovin's formula. The number of minimum sample taken was determined by using Slovin's formula as follows (Umar, 2008).

$$
n=\frac{N}{1+N \cdot e^{2}}
$$

Information :

$\mathrm{n}=\quad$ sample size/number of sample member

$\mathrm{N}=\quad$ population size/number of population member

$\mathrm{e}=\quad$ error level in taking sample

The population is $1.436(\mathrm{~N}=1.436)$. The error level in taking sample is $10 \%(\mathrm{e}=10 \%)$. Thus, the number of sample or minimum size sample is

$$
\begin{aligned}
& n=\frac{1.436}{1+1.436 \cdot(10 \%)} \\
& n=\frac{1.436}{1+1.436 \cdot(0,01)} \\
& n=\frac{1.436}{15,36}=93,49 \text { becomes } 94
\end{aligned}
$$

Based on the calculation, the smallest sample taken is 94 customers in the village credit institution of Pekraman, Tabanan.

\section{Sample Determination Methods}

The sample determination method in this study was Insidental Sampling. Insidental Sampling is a sample determination technique that is accidental. People that was accidentally met by the researcher whom they are customers in the village credit institution will be used as sample, as long as it is suitable (Sugiyono, 2014:122).

\section{Data Collection Methods}

To obtain data needed in this study, it was used some data collection techniques, such as observation, interview, documentation, and literature review. The questionnaire used Likert scale consisting of strongly disagree, disagree, neutral, agree, and strongly agree. Each answer is given an integrity with scale as follows : 


$\begin{array}{ll}\text { Strongly agree } & =5 \\ \text { Agree } & =4 \\ \text { Neutral } & =3 \\ \text { Disagree } & =2 \\ \text { Strongly disagree } & =1\end{array}$

\section{Research Instrument}

\section{Validity Test}

The validity test can be conducted by correlating between the score of factor and total score. If the correlation in each factor has a positive value $(r>0,3)$, the research instrument can be categorized as valid. The validity test in this study was conducted by using SPSS 23.0.

\section{Reliability Test}

The instrument can be categorized as reliable if it has Cronbach Alpha value $>0,60$ (Sugiyono, 2015). The reliability test was conducted by using SPSS 23.0 .

\section{Technique of Data Analysis}

\section{Descriptive Statistics Analysis}

Descriptive statistics analysis is an analysis that focuses on gathering, processing, serving and analyzing data (Wahyuni, (2011:2)). In this study, the analysis was used to describe the data that has been gathered and serve in the form of graph or table.

\section{Path Analysis}

The data analysis used to solve the problem formulation in this study was Path Analysis.

Designing path analysis: Path analysis is a special application with basic analysis of regression and correlation used to analyze the correlation among variables that aims to know the direct effect or indirect effect of indepent variable on the dependent variable (Riduwan dan Kuncoro, (2014:2)). In this study, it used one independent variable, one dependent variable, and one mediator variable. Thus, the equation of path analysis is as follows :

Sub-Structure 1:

$$
M=\beta_{1} X+e
$$

Sub-Structure 2:

$$
Y=\beta_{1} X+\beta_{2} M+e
$$

Information:

$$
\begin{aligned}
& Y=\text { Dependent Variable } \\
& X=\text { Independent Variable } \\
& M=\text { Mediator Variable } \\
& \mathrm{e}=\text { Residual Value }
\end{aligned}
$$

Examining assumption in path: To examine the assumption, it can be conducted by viewing the theoretical model that has been constructed and focusing on the form. The relationship among variables is linear. The current system is one direction where the relationship among ei is 
independent. The relationship among ei and $\mathrm{x}$ are independent and there is no dependent variable that has contradictory effect.

Estimating the parameter or counting the coefficient of path: In the path analysis, the direct effect is stated by coefficient of $\rho_{\mathrm{i}}$, while the indirect effect and total effect can be counted by self-counting. To estimating the parameter, it was conducted by using analysis of regression with SPSS 22.0.

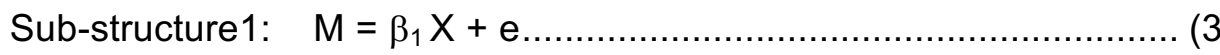

$$
\begin{aligned}
& \text { Sub-structure 2: } \quad Y=\beta_{1} X+\beta_{2} M+e
\end{aligned}
$$

Examining model validity: There are two factors to examine the model validity, namely coefficient of total determination and theory trimming (omitting non significant path in order to obtain model supported by empirical data)

\section{Sobel Test}

The testing step with sobel test is as follows (Hair et al. dalam Wibawa, 2013).

Examining the direct effect of independent variable $(X)$ on the dependent variable $(Y)$ in the model involving mediator variable (M).

Examining the effect of independent variable $(X)$ on the dependent variable $(Y)$ in the model involving mediator variable (M).

Examining the effect of independent variable $(X)$ on the mediator variable $(M)$.

Examining the effect of mediator variable $(X)$ on the dependent variable $(Y)$

According to (2013), there are some steps that can be conducted to determine the level of intervension from mediating variable as follows.

If in the testing conducted among variables, it is found :

The effect of independent variable on the mediator variable (3) is significant The effect of mediator variable on the dependent variable (4) is significant The direct effect of independent variable on the dependent variable involving mediator variable (1) is not significant

The direct effect of independent variable on the dependent variable without involving mediator variable (2) is significant

Thus, the mediator variable can be categorized as a complete mediation.

If in the testing conducted among variables, it is found :

The effect of independent variable on the mediator variable (3) is significant

The effect of mediator variable on the dependent variable (4) is significant

The direct effect of independent variable on the dependent variable involving mediator variable

(1) is significant

The direct effect of independent variable on the dependent variable without involving mediator variable (2) is significant

Thus, the mediator variable can be categorized as a partial mediation.

If in the testing conducted among variables, it is found : 
The effect of independent variable on the mediator variable (3) is significant

The effect of mediator variable on the dependent variable (4) is significant

The direct effect of independent variable on the dependent variable involving mediator variable

(1) is significant

The coefficient 2 and 1 have almost the same values

Thus, the mediator variable can be categorized as a non mediator variable.

If in the testing conducted among variables, it is found the results of testing (3) and (4) are not significant, the mediator variable can be categorized as a non mediator variable.

\section{Result of Instrument Testing}

\section{Description of Research Variable}

The result of descriptive statistics can be viewed on the table 4.8 as follows.

Table 2: Descriptive Statistics

\begin{tabular}{|l|l|l|l|l|l|}
\hline Descriptive Statistics & N & Minimum & Maximum & Mean & Std. Deviation \\
\hline & 94 & 9 & 25 & 19.80 & 2.917 \\
\hline X & 94 & 11 & 30 & 23.54 & 3.320 \\
\hline Y & 94 & 10 & 20 & 16.30 & 2.189 \\
\hline Valid N (listwise) & 94 & & & & \\
\hline
\end{tabular}

Source: Appendix 5

Based on the table 4.8, the minimum value that can be reached on the services quality is 9 and the maximum one is 25 . The mean of services quality is 19,80 . The standard deviation is 2,917 . It means that there is a deviation of services quality on the average value as many as 2,917 . For the customers' satisfaction, the minimum value is 11 and the maximum one is 30 .

The mean of customers' satisfaction is 23,54 . It means the average value of customers' satisfaction is 23,54 . The standard deviation is 3,320 . It means that there is a deviation of customers' satisfaction on the average value as many as 3,320. For the customers' loyalty, the minimum value is 10 and the maximum one is 20 . The mean of customers' loyalty is 16,30 . It means that the average value of customers' loyalty is 16,30 . Th standard deviation is 2,189 . It means that there is a deviation of customers' loyalty on the average value as many as 2,189 .

\section{Path Analysis}

Designing model based on theory

Theoretically, the relationship among variables can be made as a model in the form of path diagram as follows. 


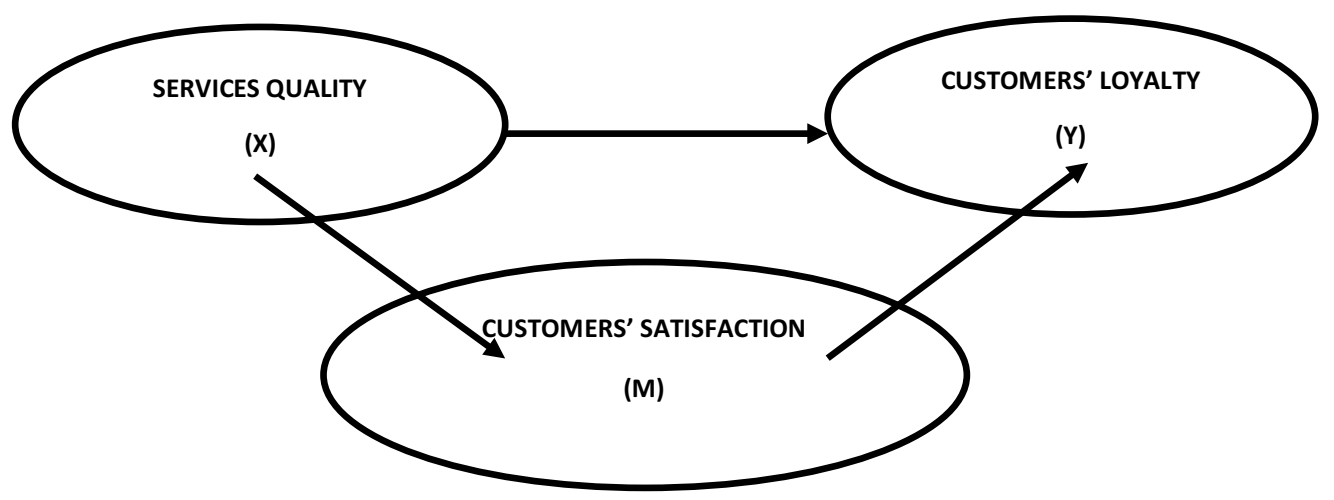

Figure 2: The Path Model for the Relationship among Services Quality, Customers' Loyalty anf Customers' Satisfaction

That model can be also stated in an equation. Thus, it creates an equation system as follows.

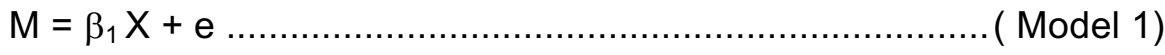

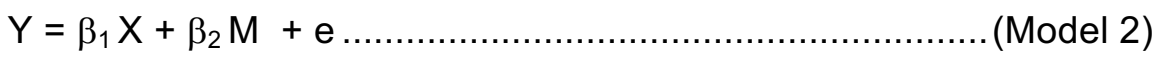

Examining assumption in path: To examine the assumption, it can be conducted by viewing the theoretical model that has been constructed and focusing on the form. The relationship among variables is linear. The current system is one direction where the relationship among ei is independent. The relationship among ei and $x$ are independent and there is no dependent variable that has contradictory effect.

Estimating the parameter or counting the coefficient of path: In the path analysis, the direct effect is stated by coefficient of $\rho_{\mathrm{i}}$, while the indirect effect and total effect can be counted by self-counting. To estimating the parameter, it was conducted by using analysis of regression with SPSS 23.0. It is obtained a result as follows.

Sub-Structure 1:

$$
M=\beta_{1} X+e
$$

From the calculation in data testing, it is obtained a result as follows.

\begin{tabular}{|c|c|c|c|c|c|c|}
\hline \multicolumn{7}{|c|}{ Coefficients $^{\mathrm{a}}$} \\
\hline \multirow{2}{*}{\multicolumn{2}{|c|}{ Model }} & \multicolumn{2}{|c|}{ Unstandardized Coefficients } & Standardized & \multirow[t]{2}{*}{$\mathrm{t}$} & \multirow[t]{2}{*}{ Sig. } \\
\hline & & B & Std. Error & Beta & & \\
\hline \multirow[t]{2}{*}{1} & (Constant) & 4.342 & 1.244 & & 3.491 & .001 \\
\hline & $x$ & 970 & .062 & .852 & 15.605 & .000 \\
\hline
\end{tabular}

Table 3: Coefficients Substruktur 1 (Model 1)

Source : Appendix 4

Sub-Structure 2 :

$$
Y=\beta_{1} X+\beta_{2} M+e
$$

From the calculation in data testing, it is obtained a result as follows. 
Table 4: Coefficients of Sub-Structure 2 (Model 2)

\begin{tabular}{|c|c|c|c|c|c|c|}
\hline \multicolumn{7}{|c|}{ Coefficients $^{a}$} \\
\hline \multirow{2}{*}{\multicolumn{2}{|c|}{ Model }} & \multicolumn{2}{|c|}{ Unstandardized Coefficients } & Standardized & \multirow[t]{2}{*}{$\mathrm{t}$} & \multirow[t]{2}{*}{ Sig. } \\
\hline & & $\mathrm{B}$ & Std. Error & Beta & & \\
\hline \multirow[t]{3}{*}{1} & (Constant) & 2.268 & .774 & & 2.929 & .004 \\
\hline & $x$ & 297 & 069 & 396 & 4.282 & 000 \\
\hline & $\mathrm{M}$ & .346 & .061 & .525 & 5.670 & .000 \\
\hline
\end{tabular}

Source : Appendix 4

Based on the calculation on the sub-structure 1 and 2, it can be indicated the value of direct effect, indirect effect and total effect among variables. The calculation among variables is as follows.

Table 5: The Direct, Indirect, and Total Effect of Services Quality, Customers' Satisfaction and Customers' Loyalty

\begin{tabular}{|l|l|l|l|l|}
\hline Variable & $\begin{array}{l}\text { Direct } \\
\text { Effect }\end{array}$ & $\begin{array}{l}\text { Indirect Effect through } \\
\text { Satisfaction }\end{array}$ & $\begin{array}{l}\text { Total } \\
\text { Effect }\end{array}$ \\
\hline $\begin{array}{l}\text { Services } \\
\text { Quality }\end{array}$ & $\begin{array}{l}\text { Customers' } \\
\text { Satisfaction }\end{array}$ & 0,852 & & 0,852 \\
\hline Satisfaction & Customers' Loyalty & 0,525 & & 0,525 \\
\hline $\begin{array}{l}\text { Sevices } \\
\text { Quality }\end{array}$ & Customers' Loyalty & 0,396 & 0,447 & 0,843 \\
\hline
\end{tabular}

The structural equation for this model is as follows :

Sub-structure 1:

$$
\begin{aligned}
& M=\beta_{1} X+e_{1} \\
& M=0,852 X+0,82 \\
& \text { Effect of error }(P e i)=\sqrt{ } 1-R^{2} \\
& \text { Pei }=\sqrt{ } 1-0,326=0,82
\end{aligned}
$$

Sub-sructure 2:

$$
\begin{aligned}
& Y=\beta_{1} X+\beta_{2} M+e_{2} \\
& Y=0,396 X+0,525 M+0,56 \\
& \text { Effect of error }(\text { Pei })=\sqrt{ } 1-R^{2} \\
& \text { Pei }=\sqrt{ } 1-0,686=0,56
\end{aligned}
$$

Examining validity model: There are two indicators to examine the validity model, namely coefficient of total determination and theory trimming, where the result can be presented as follows.

The result of coefficient of determination is as follows :

$$
\begin{aligned}
& R^{2}{ }_{m}=1-(1-0,326)(1-0,686) \\
& R^{2}=1-0,22 \\
& R^{2}{ }_{m}=0,78
\end{aligned}
$$


It means the various data that can be explained by the model is $78,0 \%$ or the information contained in the data as many as $78,0 \%$ can be explained by the model. $22,0 \%$ can be explained by other variables (It is not contained in the model) and error.

Theory Triming: The approach was conducted by omitting the non significant path in order to obtain model supported by the empirical data. The validity test in each path for the direct effect is equal to regression using value of $p$ from T-test, namely the regression test conducted partially. The services quality $(\mathrm{X} 1)$ on the customers' satisfaction $(\mathrm{Y})$ is 15,605 with sig $=0,000$. The services quality $(\mathrm{X} 1)$ on the customers' loyalty $(\mathrm{Y})$ is 4,282 with $\mathrm{sig}=0,000$. The customers' satisfaction (M) on the customers' loyalty $(\mathrm{Y})$ is 5,670 with sig $=0,000$.

\section{Regression Analysis of Mediation Using Sobel Test}

To examine the mediator mediating the relationship between bound variable and free variable, it can be conducted as follows

The Indirect Effect of Services Quality on the Customers' Loyalty through Customers' Satisfaction

$$
\begin{aligned}
& a=0,970 \\
& s a=0,062 \\
& b=0,346 \\
& s b=0,061
\end{aligned}
$$

1) Counting the value of $S_{a b}$

$$
\begin{aligned}
& \mathrm{Sab}=\sqrt{b^{2} s a^{2}+a^{2} s b^{2}+s a^{2} s b^{2}} \\
& \mathrm{Sab}=\sqrt{(0,120 * 0,004)+(0,941 * 0,004)+(0,004 * 0,004)} \\
& \mathrm{Sab}=0,063
\end{aligned}
$$

2) Counting the value of $a b$

$$
\begin{aligned}
& a b=0,970 \times 0,346 \\
& a b=0,336
\end{aligned}
$$

3) Counting the value of $Z$

$$
\begin{aligned}
& Z=\frac{a b}{S a b} \\
& Z=\frac{0,336}{0,063} \\
& Z=5,323
\end{aligned}
$$

4) Determining $Z_{\text {table }}$ that the level of significance is $0,05(1,96)$

5) Comparing $Z_{\text {count }}(5,323)$ and $Z_{\text {table }}(1,96)$

6 ) It can be concluded that the customers' satisfaction can mediate the relationship between the services quality and customers' loyalty.

\section{Model Interpretation}

The Effect of Services Quality on the Customers' Satisfaction.

The hypothesis used is as follows.

$\mathrm{H} 1$ : The services quality affects on the customers' satisfaction in the village credit institution of Pekraman, Tabanan.

The test criteria used is as follows.

If sig $\mathrm{t}<0,05, \mathrm{H} 0$ is rejected and $\mathrm{H} 1$ is accepted.

If sig $\mathrm{t}>0,05, \mathrm{H} 1$ is rejected and $\mathrm{HO}$ is accepted. 
Based on the calculation, it is obtained the level of significance for services quality on the customers' satisfaction is $0,000<0,05$. $\mathrm{H} 0$ is rejected and $\mathrm{H} 1$ is accepted. It means the services quality of has a significant effect on the customers' satisfaction in the village credit institution of Pekraman, Tabanan.

The Effect of Customers' Satisfaction on the Customers' Loyalty

The hypothesis used is as follows.

$\mathrm{H} 2$ : The customers' satisfaction affects on the customers' loyalty in the village credit institution of Pekraman, Tabanan.

The test criteria used is as follows.

If sig $\mathrm{t}<0,05, \mathrm{H} 0$ is rejected and $\mathrm{H} 2$ is accepted.

If sig $\mathrm{t}>0,05$, maka $\mathrm{H} 2$ is rejected and $\mathrm{H} 0$ is accepted.

Based on the calculation, it is obtained the level of significance for the customers' satisfaction on the customers' loyalty is $0,000<0,05$. H0 is rejected and H2 is accepted. It means the customers' satisfaction has a significant effect on the customers' loyalty in the village credit institution of Pekraman, Tabanan.

The Effect of Services Quality on the Customers' Loyalty

The hypothesis used is as follows.

H3: The services quality affects on the customers' loyalty in the village credit institution of Pekraman, Tabanan.

The test criteria used is as follows.

If sig $\mathrm{t}<0,05, \mathrm{H} 0$ is rejected and $\mathrm{H} 3$ is accepted.

If sig $\mathrm{t}>0,05, \mathrm{H} 3$ is rejected and $\mathrm{HO}$ is accepted.

Based on the calculation, it is obtained the level of significance for the services quality on the customers' loyalty is $0,000<0,05$. $\mathrm{H} 0$ is rejected and $\mathrm{H} 3$ is accepted. It means the services quality has a significant effect on the customers' loyalty in the village credit institution of Pekraman, Tabanan.

The Effect of Services Quality on the Customers' Loyalty through Customers' Satisfaction Mediation

The hypothesis used is as follows.

$\mathrm{H} 4$ : The customers' satisfaction can mediate the relationship between the services quality and the customers' loyalty in the village credit institution of Pekraman, Tabanan.

The test criteria used is as follows.

If $Z_{\text {count }}>Z_{\text {table }}, \mathrm{HO}$ is rejected and $\mathrm{H} 1$ is accepted.

Based on the calculation, it is obtained $Z_{\text {count }}(5,323)>Z_{\text {table }}(1,96)$. Thus, the customers' satisfaction can mediate the relationship between the services quality and the customers' loyalty.

\section{Discussion}

\section{The Effect of Services Quality on the Customers' Satisfaction}

Based on the result of empirical test, it is obtained the level of significance for the services quality on the customers' satisfaction is $0,000<0,05$. $\mathrm{H} 0$ is rejected and $\mathrm{H} 1$ is accepted. It means the services quality has a significant effect on the customers' satisfaction in the village credit institution of Pekraman, Tabanan. If the customers get the best services, they will feel satisfied on all services provided by the company. It indicates the village credit institution of Pekraman, Tabanan is able to control all dimensions in the services quality, so the costumers will give a positive feedback to the company such as being satisfied in having services provided. The customers who feel satisfied will convey positive information to others about the services provided by the village credit institution of 
Pekraman, Tabanan. Thus, the objective of the village credit institution of Pekraman tabanan can be reached without any obstacles.

\section{The Effect of the Customers' Satisfaction on the Customers' Loyalty}

Based on the result of empirical test, it is obtained the level of significance for the customers' satisfaction on the customers' loyalty is $0,000<0,05$. $\mathrm{H} 0$ is rejected and $\mathrm{H} 2$ is accepted. It means the customers' satisfaction has a significant effect on the customers' loyalty in the village credit institution of Pekraman, Tabanan. The village credit institution of Pekraman, Tabanan offers the specification of products in accordance with the customers' expectation. It will surely make the customers feel satisfied. Products having positive image and being in accordance with the customers' expectation will make the customers satisfied. If they feel satisfied, the will repurchase. It is called loyalty. They purchase products for many times in different time and in accordance with their needs. The customers' loyalty is indicated by giving positive information and recommending the village credit institution of Pekraman, Tabanan to others.

\section{The Effect of Services Quality on the Customers' Loyalty}

Based on the result of empirical test, it is obtained the level of significance for the services quality on the consumers' loyalty is $0,000<0,05$. $\mathrm{H} 0$ is rejected and $\mathrm{H} 3$ is accepted. It means the services quality has a significant effect on the customers'loyalty in the village credit institution of Pekraman, Tabanan. The customers who feel satisfied on the services provided by the company will affect on the customers' loyalty. The loyal customers will come again. Then they will consume the products or uses the services offered by the company. Thus, the village credit institution of Pekraman, Tabanan must be able to preserve its services quality by providing trainings to the employees in order to have better quality in giving services to the customers.

\section{The Effect of Services Quality on the Customers' Loyalty through Customers' Satisfaction Mediation}

Based on the result of empirical test, it is obtained $Z_{\text {count }}(5,323)>Z_{\text {table }}(1,96)$. It means the customers'satisfaction can mediate the relationship between the services quality and the customers' loyalty. The customers' loyalty creates a good and long relationship between the company and the customers. In addition, the cost used for obtaining new customers is greater than the cost used for maintaining the loyal customers. The customers' loyalty cannot be separated from customers' satisfaction. Either practicioner or academician states that satisfaction and loyalty is related and cannot be separated, but not all customers' satisfaction refer to loyalty. The relationship pattern among them is asymmetrical. The loyal customers are mostly customers feeling satisfied.,

\section{Conclusion}

Based on the result of data analysis and discussion, there are some conclusions as follows :

Based on the result of calculation, the level of significance for the services quality on the customers' satisfaction is 0,000 < 0,05. HO is rejected and $\mathrm{H} 1$ is accepted. It means the services quality has a significant effet on the customers' satisfaction in the village credit institution of Pekraman, Tabanan.

Based on the result of calculation, the level of significance for the customers' satisfaction on the customers' loyalty is 0,000 < 0,05. HO is rejected and H1 is accepted. It means the customers' satisfaction has a significant effect on the customers' loyalty in the village credit institution of Pekraman, Tabanan. 
Based on the result of calculation, the level of significance for the services quality on the customers' loyalty is $0,000<0,05$. $\mathrm{HO}$ is rejected and $\mathrm{H} 3$ is accepted. It means the services quality has a significant effect on the customers in the village credit institution of Pekraman, Tabanan.

Based on the result of calculation, it is obtained $Z_{\text {count }}(5,323)>Z_{\text {table }}(1,96)$. Thus, the customers' satisfaction can mediate the relationship between services quality and customers' loyalty in the village credit institution of Pekraman, Tabanan.

\section{Suggestion}

Based on the result, it can be suggested as follows :

For the services quality, it is needed to improve the services given to the customers, especially giving exciting interest in accordance with the type of saving chosen by them. Thus, they will feel satisfied and can improve their loyalty.

The management of village credit institution is expected to give the best services to all customers, such as providing comfortable waiting room and good services in order to make them satisfied and loyal to the village credit institution.

The employee of village credit institution is expected to work professionally and be able to fulfill or help the customers finding difficulties in transactions. Based on the criteria responses, it indicates that the consumers have not got optimum and quick services yet.

For the next study, it is suggested that the next researcher can add variables having other effect so the factor that greatly affects on the customers' loyalty can be indicated. It also needs to take a research again to obtain information about the improvement of customers' loyalty after improving the services quality and focusing on the customers' satisfaction. The coefficient of determination obtained in this study is $78,00 \%$ and $22,00 \%$ is affected by variables or other reasons out of the research model.

\section{References}

Abdullah, M. Faisal. 2005. Manajemen Perbankan. Malang : Universitas Muhammadiyah

Ahmad Mardalis.2005. "Meraih Loyalitas Nasabah", Benefit: Jurnal Manajemen dan Bisnis FE UMS Surakarta, (Volume 9, No. 2, Desember, p. 111-119).

Al- Rasyid, H. 1994. Analisis jalur (Path Analysis) sebagai sarana Statistika dalam Analisis Kausal. Bandung : LP3S Fakultas Ekonomi UNPAD.

Alma, Buchari. 2009. Manajemen Pemasaran dan Pemasaran Jas. Bandung : Alfabeta

Ani,S. 2012 " Pengaruh Atribut Produk Tabungan Terhadap Loyalitas Nasabah ( studi pada Bank XYZ KCP Antapati Bandung)

Ariani, D. Wahyu. 2009. Manajemen Operasi Jasa. Cetakan Pertama. Graha IImu. Yogyakarta.

Arikunto, Suharsimi, 2002. Prosedur Penelitian Suatu Pendekatan Praktis. Jakarta : Rineka Cipta.

Bhuono Agung Nugroho, 2005,Strategi Jitu Memilih Metode Statistik Penelitian dengan SPSS, Penerbit Andi, Yogyakarta

Buku Pedoman Penulisan Usulan Penelitian 2016 Fakultas Ekonomi, Universitas Hindu Indonesia Denpasar. 
Daulay, Raihanah. 2006. Pengaruh Pelayanan, Bagi Hasil, Dan Keyakinan Terhadap Keputusan Menabung Nasabah Pada Bank Syariah Mandiri Cabang Utama Medan. Tesis Diterbitkan. Medan : Sekolah Pasca Sarjana Universitas Sumatra Utara

David.A. Aaker,2007,Managing Brand Equity. New York ; The Free Press

Dharma Diyanthini Ni Putu, Seminari Ni Ketut, Jurnal :Pengaruh Citra perusahaan Perusahaan,Promosi penjualan dan kualitas pelayanan terhadap kepuasan nasabah pada LPD Desa Pakraman Panjer.

Eko B, Supriyanto, 2004, "Peta Baru Pelayanan Bank", InfoBank, No.272, Vol.XXXIV, Maret, hal.1221.

Ernani Hadiyati.2010 "Analisis Kualitas Pelayanan dan Pengaruhnya Terhadap Loyalitas Nasabah" (studi kasus pada PT. POS Indonesia (persero) Kantor Pos Lawang

Ernest R. Hilgard, 2005, Introduction to psychology,Bandung : Harcourt Offset

Fauzi, Yayan. 2010. Faktor - Faktor Yang Mempengaruhi Nasabah Di Perbankan Syariah (Kasus Pada Bank BNI Syariah Kantor Cabang Yogyakarta).

Ghozali, Imam. 2006. Aplikasi Analisis Multivariate dengan Program SPSS. Semarang : Universitas Diponegoro

Gilbert A. Churchill, 2007, Marketing Reseach :Methodological Foundations, Bandung : Harcourt Offset

http://jurnal-sdm.blogspot.co.id/2009/07/produk-definisi-klasifikasi-dimensi-30. html

http://www.bukopin.co.id/read/70/Bukopin_Prioritas_.html

Indra, Karma Jusi, 2004, "Pelayanan, Loyalitas, dan Profit Perbankan", InfoBank, No.272, Vol.XXXIV, Maret, hal.38-39.

Isti Faradisa, Kepuasan Nasabah,Fasilitas, dan Kualitas Pelayanan, Terhadap Minat Bli Ulang pada (ICOS CAFÉ), jurnal of managrment, volume 2 no 2 maret 2016.

Jasfar, Farida (2000), Kualitas Jasa dan Hubungannya Dengan Loyalitas Serta Komitmen : Studi Pada Nasabah Salon Kecantikan, Jurnal Siasat Bisnis, No. 7 Vol. 1 Tahun 2002, Hal $43-64$.

Kasmir. 2012 ${ }^{\mathrm{a}}$. Manajemen Perbankan. Raja Grafindo Persada.Jakarta.

Kasmir. 2012 ${ }^{\text {b }}$. Dasar-dasar Perbankan. Rajawali Pers. Jakarta.

Kotler, Philip, (1997), Dasar-dasar Pemasaran, Alih Bahasa Alexander Sindoro, Prenhalindo, Jakarta.

Kotler, Philip, 2000, Marketing Management, The Milenium Edition, Ten edition, USA : Prentice Hall, Inc.

Kottler, Phillip, 2003, Manajemen Pemasaran: Analysis, Perencanaan, Implementasi dan Pengendalian, Edisi Bahasa Indonesia, Jakarta: Salemba Empat - Prentice Hall.

Lovelock, Christoper dan Lauren, Wright. 2007. Manajemen Pemasaran Jasa. Cetakan II.Indeks. Jakarta

Lupiyoadi, Rambat. 2013. Manajemen Pemasaran Jasa. Jakarta : Salemba Empat Muslimin.2002. Metode Penelitian Bidang Sosial.Malang : Bayu Media \& UMM Press

Machfoedz, Mahmud. 2005. Pengantar Pemasaran Modern. Cetakan Pertama. Akademi Manajemen Perusahaan YKPN. Yogyakarta

Mulyo dan Ukudi, Kualitas layanan, Kepercayaan, dan Komitmen ,Terhadap loyalitas Nasabah(PD. BPR Bank Pasar Kendal) jurnal bisnis dan Ekonomi(JBE), September 2077, Hal. 215-227

Mustika Ari Ni Wayan, 2009, Skripsi :Analisis Kualitas Layanan Terhadap Kepuasan Nasabah Kreditdi LPD Desa Adat Kuta

Parasuraman, A., (1988), Delivering Quality Service Balancing Customer Perceptions and Expectation, The Fress Press, New York.

Philip R. Cateora, 2002, International Marketing, Bandung : Harcourt Offset 
Reynolds, Kristy E, and Sharon E Beatty, 1999, Customer Benefits and Company Consequences of Customer-salesperson Relationships in Retailing, Journal of Retailing, Volume 75 (1),pp 11-32.

Saifuddin, Azwar, (1997), Reliabilitas dan Validitas, Edisi ke tiga Cetakan Pertama,Pustaka Pelajar, Yogyakarta

Sigit Sujarwo, Produk dan Kualitas Pelayanan Terhadap Loyalitas Nasabah Tabungan Britama Pada PT Bank Rakyat Indonesia (persero) Tbk Cabang Semarang Pandanaran.

Singgih Santoso, 2005, Statistik Parametrik dengan SPSS, Jakarta, Elex Komputindo

Sinungan,Muchdarsyah. 2005, Produktivitas apa dan bagaimana, Jakarta : PT.Bumi Aksara

Sitepu, Nirwana SK. 1994. Analisis jalur (path Analysis). Bandung : Jurusan FMIPA Universitas Statistika Padjadjaran.

Soeganda Priyatna dan Elvinaro Ardianto, 2009, Tujuh Pilar Strategi Komunikasi Bisnis, Bandung : Widya Padjadjaran

Sudjana, 2003. Statistik Untuk Ekonomi dan Niaga. Bandung : Tarsito

Sugiyono. 2014. Metode Penelitian Bisnis. Alfabeta. Bandung.

Suparyadi. "Membangun Loyalitas Nasabah; perlombahaan tanpa garis finis",

Supranto, J. 2001. Pengukuran Tingkat Kepuasan Nasabah. Jakarta: PT Rineka Cipta.

Sutisna 2002. Perilaku Konsumen \& Komunikasi Pemasaran, Bandung : PT. Remaja Rosdakarya.

Sutojo, Siswanto, 2007, Membangun Citra perusahaan Perusahaan, Jogjakarta : Damar Mulia Pustaka.

Tjiptono, F \& Chandra, G. 2012. Pemasaran Strategik. Edisi 2. Andi

Umar, Husain. 2001. Metode Penelitian untuk Skripsi dan Tesis.Jakarta :PT Raja Grafindo Persada.

Utomo, Toni Prasetya. 2014. Analisis Faktor- Faktor Yang Mempengaruhi Keputusan Nasabah Dalam Memilih Jasa Perbankan Syariah (Studi Pada Bank Syariah Mandiri, Kantor Cabang Malang).Jurnal IImiah Mahasiswa Fakultas Ekonomi dan Bisnis Universitas Brawijaya, Vol. 3, (No.1) : 1-24.

Wahyono. 2010. Manaemen Pemasaran Bank. Cetakan Pertama. Graha IImu Yogyakarta. 